Brit. J. vener. Dis. (1964), 40, 125.

\title{
IMMUNOFLUORESCENCE TECHNIQUES AS AN AID TO THE DIAGNOSIS OF GONORRHOEA*
}

\author{
BY \\ C. S. FRY AND A. E. WILKINSON \\ Venereal Diseases Reference Laboratory, The London Hospital
}

The technique of staining antigens with a fluorescent dye coupled to specific antibody was first applied to the identification of $N$. gonorrhoeae by Deacon, Peacock, Freeman, and Harris (1959). From this and further studies they concluded that the fluorescent antibody (F.A.) technique was superior to conventional cultural diagnostic methods and afforded a considerable saving in labour and materials and in the time required for making a bacteriological diagnosis (Deacon, Peacock, Freeman, Harris, and Bunch, 1960). Similar studies on material from patients have been reported by Harris, Deacon, Tiedemann, and Peacock (1961), Lind (1962), Brown, Copeloff, and Peacock (1962), Moore, VanderStoep, Wende, and Knox (1963), and Danielsson (1963).

The present study was undertaken to compare F.A. techniques with established methods for the diagnosis of gonorrhoea and to assess their applications to routine work.

\section{Materials and Methods}

\section{Preparation and Conjugation of Antigonococcal Sera}

The growth from 18-hr cultures of four freshly-isolated strains of gonococci on chocolate agar slopes was pooled, washed twice with sterile saline, and resuspended in $4 \mathrm{ml}$. saline. This suspension was emulsified in an equal volume of Freund's complete adjuvant and $1.25 \mathrm{ml}$. of the emulsion was inoculated subcutaneously into the hind legs of young rabbits. A similarly prepared booster dose prepared from four further freshly-isolated strains of gonococci was given after 4 weeks and the animals bled out 3 weeks later after a trial had shown that complementfixing antibodies to a suspension of gonococci were present to a high titre.

The globulin fraction of the antiserum was separated by half saturation with ammonium sulphate and after dialysis was conjugated with fluoresceine isothiocyanate by the method of Chadwick and Fothergill (1962), using a fluoresceine: protein ratio of $0 \cdot 035: 1 \cdot 0$. Unreacted fluoresceine was removed from the conjugate by passage

\footnotetext{
* Received for publication July 5, 1963.
}

through a Sephadex G 25 column and elution with phosphate buffered saline, $\mathrm{pH} 7 \cdot 3$, followed by absorption with acetone-dried guinea-pig kidney tissue powder.

On testing the conjugate against urethral smears from males with acute gonorrhoea, it was found that, while good labelling of gonococci was achieved, differentiation of the organisms from the background fluorescence of the leucocytes in the smears was difficult. Lind (1962) mentions the same problem. This was largely overcome by using normal rabbit globulin conjugated with Lissamine Rhodamine $\mathbf{B}$ as a background counterstain, as suggested by Smith, Marshall, and Eveland (1959). This conjugate was prepared by the method of Chadwick and Fothergill (1962) and for use was mixed with an equal volume of the fluoresceine-conjugated anti-gonococcal globulin. The proportions in which the two conjugates were mixed was determined for each batch made. The mixture gave a reddish-orange fluorescence to the leucocytes and other background material and afforded a good contrast to the green fluorescence of the labelled gonococci.

\section{Direct F.A. Test}

Thin smears of secretions, diluted if need be in tap water, were fixed by gentle heat and incubated with the mixed conjugates for one hour at $35 \mathrm{C}$. in a moist chamber. After washing in two changes of buffered saline, $\mathrm{pH} 7 \cdot 3$, the slides were mounted in buffered glycerine.

\section{Delayed F.A. Test}

Secretions were inoculated on chocolate agar slopes in bijou bottles and incubated at $35^{\circ} \mathrm{C}$. for 18 to $24 \mathrm{hrs}$. Smears of the mixed growth were fixed by heat and treated as in the direct test.

\section{Optical Equipment}

Slides were examined under dark-ground illumination using a Zeiss $1 / 12^{\prime \prime}$ objective with an iris diaphragm and a $\times 4$ eyepiece. The illuminating source was a ME/D 250 watt high pressure mercury vapour lamp, light from which was passed through a $1 \mathrm{~cm}$. trough of 5 per cent. $\mathrm{CuSO}_{4}$ to remove residual red light and a ChanceWatson OB 10 filter transmitting in the 340-550 $\mathrm{m} \mu$ range. A Watson $O Y 12$ barrier filter was used on the eyepiece. 


\section{Routine Cultural Methods}

Specimens were taken on charcoal-impregnated swabs in Stuart's transport medium; these were kept in a refrigerator until they could be inoculated on to chocolate agar plates, usually after an interval of 18 to $24 \mathrm{hrs}$. Plates were incubated at $35^{\circ} \mathrm{C}$. in candle jars for $48 \mathrm{hrs}$. Gram-negative diplococci which were oxydase positive and had the colonial and microscopical morphology of gonococci were reported as "Presumptive" gonococci and subcultures made where possible to 1 per cent. glucose and maltose hydrocele agar slopes to complete the identification.

\section{Results}

Series 1

Direct and delayed F.A. tests were carried out on the urethral secretions of 100 men with acute gonococcal urethritis diagnosed on the finding of intracellular Gram-negative diplococci in stained films of secretion. In eighteen cases the routine cultures were overgrown by contaminating organisms so that a full comparison could not be made. The results in the remaining 82 cases show that one or both the fluorescence tests were found positive in all but one of them (Table I). Both tests were also positive in seventeen of the eighteen cases in which the routine cultures were contaminated; in the remaining case both were negative.

\section{TABLE I}

COMPARISON OF THE RESULTS OF FLUORESCENCE TESTS AND CULTURES IN 82 CASES OF ACUTE GONORRHOEA

\begin{tabular}{|c|c|c|c|c|c|c|}
\hline F.A. & & $\begin{array}{l}\text { Direct } \\
\text { Delayed }\end{array}$ & $\begin{array}{l}+ \\
+\end{array}$ & $\begin{array}{l}+ \\
-\end{array}$ & $\begin{array}{l}- \\
+\end{array}$ & - \\
\hline $\begin{array}{l}\text { Gram film } \\
\text { Culture }\end{array}$ & $\begin{array}{l}\cdots \\
\ldots\end{array}$ & $\begin{array}{l}+ \\
+\end{array}$ & 65 & 5 & 5 & 1 \\
\hline $\begin{array}{l}\text { Gram film } \\
\text { Culture }\end{array}$ & $\begin{array}{l}\cdots \\
\cdots\end{array}$ & $\begin{array}{l}+ \\
-\end{array}$ & 4 & 1 & 1 & 0 \\
\hline
\end{tabular}

Direct and delayed F.A. tests were also carried out on the urethral and cervical secretions in parallel with routine tests on 47 female patients in whom the diagnoses of gonorrhoea had been made by the examination of stained smears, or who were contacts of males with gonorrhoea, or who were being investigated to exclude the condition. Table II, in which the figures relate to the number of sites examined, shows that the fluorescence tests gave more positive results than the conventional tests: 65 per cent. of the sites were found positive by the direct F.A., $57 \cdot 5$ per cent. by the delayed F.A., 53 per cent. by routine culture, and 51 per cent. by
TABLE II

COMPARISON OF THE RESULTS OF FLUORESCENCE TESTS AND ROUTINE METHODS IN 47 FEMALE PATIENTS

\begin{tabular}{|c|c|c|c|c|c|c|}
\hline F.A. & & $\begin{array}{l}\text { Direct } \\
\text { Delayed }\end{array}$ & $\begin{array}{l}+ \\
+\end{array}$ & + & $\begin{array}{l}- \\
+\end{array}$ & - \\
\hline $\begin{array}{l}\text { Gram film } \\
\text { Culture } \quad . .\end{array}$ & $\begin{array}{l}\cdots \\
\ldots\end{array}$ & $\begin{array}{l}+ \\
+\end{array}$ & 23 & 3 & 5 & 2 \\
\hline $\begin{array}{l}\text { Gram film } \\
\text { Culture } \quad . .\end{array}$ & $\begin{array}{l}\cdots \\
\cdots\end{array}$ & + & 7 & 7 & 1 & 0 \\
\hline $\begin{array}{l}\text { Gram film } \\
\text { Culture } \quad . .\end{array}$ & $\begin{array}{l}\cdots \\
\ldots\end{array}$ & $\begin{array}{l}- \\
+\end{array}$ & 8 & 4 & 3 & 2 \\
\hline $\begin{array}{l}\text { Gram film } \\
\text { Culture } \quad .\end{array}$ & $\begin{array}{l}\cdots \\
\ldots\end{array}$ & - & 5 & 4 & 2 & 18 \\
\hline
\end{tabular}

stained smears. It should be noted, however, that four sites were found positive by culture where the fluorescence tests were both negative. A further eleven sites were positive by one or both the fluorescence tests although the cultures and smears from these sites were negative. These specimens came from eight patients, seven of whom had positive smears or cultures from other sites; the eighth was a contact of a known case of gonorrhoea but her smears and cultures were all negative and she defaulted from observation after a single attendance.

\section{Series 2}

This series comprised 47 women diagnosed as having gonorrhoea on the basis of stained smears or in whom the diagnosis was to be excluded. Direct F.A. tests were not performed, but smears of the growth in the area of the primary inoculum on the chocolate agar plates used for the routine cultures, were examined by the fluorescence test after the plates had been incubated for $24 \mathrm{hrs}$. The method thus resembles the delayed F.A. method used in the first series except that an overnight period in Stuart's transport medium preceded culture. Specimens of urethral, cervical, and vaginal secretions were examined in all cases and in 27 cases material from the rectum in addition. The results are analysed according to sites in Table III.

TABLE III

COMPARISON OF DELAYED F.A. TESTS AND CULTURES FROM 47 FEMALE PATIENTS

\begin{tabular}{|c|c|c|c|c|}
\hline \multicolumn{2}{|c|}{ Site } & $\begin{array}{l}\text { Number } \\
\text { of Cases }\end{array}$ & $\begin{array}{l}\text { Culture } \\
\text { Positive }\end{array}$ & $\underset{\text { Positive }}{\text { Delayed F.A. }}$ \\
\hline $\begin{array}{l}\text { Urethra } \\
\text { Cervix .. } \\
\text { Vagina } \\
\text { Rectum }\end{array}$ & $\begin{array}{l}. \\
\cdots \\
\ldots\end{array}$ & $\begin{array}{l}47 \\
47 \\
47 \\
27\end{array}$ & $\begin{array}{r}16 \\
24 \\
16 \\
4\end{array}$ & $\begin{array}{r}18 \\
27 \\
20 \\
4\end{array}$ \\
\hline
\end{tabular}


In this group of tests the delayed F.A. method gave slightly more positive results than the routine cultures. This is partly accounted for by the finding that eleven cultures had become overgrown by Proteus when the plates were examined at $48 \mathrm{hrs}$, and in seven of these the fluorescence test gave a positive result on material removed after overnight incubation. These discrepancies related to five patients, brief details of whom are as follows:

Case 1: Gonorrhoea treated with 600,000 units procaine penicillin on $17 / 11 / 62$. Smears and cultures negative 23/11/62 but delayed fluorescence tests positive on urethra and cervix. Smears and cultures again positive $1 / 1 / 63$; further sexual exposure denied.

Case 2: Previous history of gonorrhoea with positive cultures in August, 1961. Complained of discharge and lower abdominal pain 21/11/62. Smears and urethral and cervical cultures negative but rectal and vaginal cultures overgrown by Proteus. Delayed F.A. tests positive on cervical and vaginal specimens.

Case 3: No previous history of gonorrhoea. Contact had non-gonococcal urethritis but had also had gonorrhoea in July, 1962. Smears and cultures negative, G.C.F.T. positive 27/10/62. Smears and and cultures negative, G.C.F.T. positive $4 / 3 / 63$. Delayed F.A. test positive in vaginal specimen.

Case 4: Cervical smear positive. Cultures overgrown by Proteus. Delayed F.A. tests positive on cervical and vaginal specimens.

Case 5: No previous history of gonorrhoea. Marital contact showed no evidence of venereal disease. Smears negative, cultures overgrown by Proteus. Delayed F.A. tests positive on urethral, cervical, and vaginal specimens.

In Cases 1, 4, and possibly 3, the fluorescence results would appear valid, whereas in Cases 2 and 5 they were not supported by other evidence suggestive of gonorrhoea.

\section{Discussion}

The results obtained in this preliminary survey are in broad agreement with previous reports and suggest that the F.A. techniques are a sensitive means for the identification of gonococci in secretions from patients. In our hands the direct F.A. method gave a higher proportion of positive results than other workers have reported. Thus Deacon and others (1960) found 14.6 per cent. of sites positive by direct F.A. against 43.7 per cent. by the delayed method in tests on fifty female contacts of males with gonorrhoea. Lind (1962) found a close agreement between the two methods in tests on secretions from the male urethra but only thirty positive results by the direct as compared with 52 by the delayed method in tests on 103 female patients. Danielsson (1963), in tests on 93 males, found the direct F.A. positive in 37 cases and the delayed F.A. positive in 52. The use of a rhodamine conjugate to give a contrasting background may have contributed to the higher proportion of positive direct tests found in the present series.

The successful application of immunofluorescence procedures to the identification of micro-organisms depends ultimately on the specificity of the antiserum used. In this connexion the question of shared antigens between various bacteria and the presence of antibacterial antibodies, either natural or acquired, in the animal before immunization merit consideration. In the latter case, such antibodies, if present will be conjugated along with the desired specific antibody produced by immunization. Lind (1962) found that her antigonococcal serum reacted with some 10 per cent. of strains of coagulase-positive staphylococci, giving these organisms the same intensity of staining as gonococci. Danielsson (1963) has reported results which suggest that gonococci may have an antigenic relationship with staphylococci. Deacon and others (1959) reported crossreactions of antigonococcal conjugates with meningococci and to a lesser extent with $N$. catarrhalis.

The conjugate used in the present work showed fairly strong fluorescence with a strain of meningococcus and very weak reactions with $N$. pharyngis and $N$. catarrhalis. Absorption with $N$. pharyngis and $N$. catarrhalis practically eliminated crossreactions but also reduced the brilliance of staining of gonococci to some extent; it was not adopted as a routine procedure. 88 strains of Staph. pyogenes were examined; five of these showed a very pale fluorescence which was not thought to be likely to cause confusion with the much more intense specific reaction with gonococci. Tests against 23 strains of Staph. saprophyticus and three of streptococci isolated from the genital tract were negative, as were tests with seven strains of organisms belonging to the Mima-Herellea group. Although this particular conjugate appeared to be free from antibody likely to cause difficulty in the recognition of the gonococcus, it is thought that similar surveys should be carried out on antisera before they are used for diagnostic purposes. Other Neisseria besides the gonococcus do occur in the genital tract, albeit rarely, and to avoid mistaking these for gonococci, it will be necessary in future work to remove crossreacting antibody from the antisera used. 
Besides the advantages of speed and simplicity, the delayed F.A. method is helpful in that it is often possible to demonstrate the presence of gonococci when there are large numbers of other organisms which often overgrow the gonococcus on conventional culture plates, particularly when the latter are scanty and difficult or impossible to isolate in pure culture. In the present study attention was directed primarily to testing known cases of gonorrhoea to assess the sensitivity of the fluorescence methods. The results are considered encouraging and the new technique should prove useful as an ancillary to conventional cultural methods in the investigation of patients who are likely to have gonorrhoea (such as contacts or sexually promiscuous persons) but in whom existing methods fail to show the presence of gonococci.

\section{Summary}

Immunofluorescence tests using an antigonococcal serum conjugated with fluoresceine isothiocyanate were carried out on 100 male and 94 female patients. The results are compared with those of Gramstained smears and cultures. A higher proportion of positive results was obtained by the fluorescence methods than by either smears or cultures. The advantages of the method and the importance of the use of a specific antiserum which does not crossreact with other organisms are discussed.

Our thanks are due to Mrs D. Birch and Miss B. Jones for their help with the examination of routine cultures for gonococci.

\section{REFERENCES}

Brown, L., Copeloff, M. B., and Peacock, W. L. (1962). Amer. J. Obstet. Gynec., 84, 753.

Chadwick, C. S., and Fothergill, J. E. (1962). In "Fluorescent Protein Tracing”, ed. R. C. Nairn, pp. 4-30. Livingstone, Edinburgh.

Danielsson, D. (1963). W.H.O. Documents WHO/VDT/ $\mathrm{RES} / \mathrm{Gon} / 3$ and 4.

Deacon, W. E., Peacock, W. L., Freeman, E. M., and Harris, A. (1959). Proc. Soc. exp. Biol. (N.Y.), 101, 322.

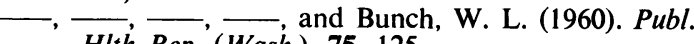
Hlth Rep. (Wash.), 75, 125.

Harris, A., Deacon, W. E., Tiedemann, J., and Peacock, W. L. (1961). Ibid., 76, 93.

Lind, I. (1962). W.H.O. Document WHO/VDT/295.

Moore, M. B., VanderStoep, E. M., Wende, R. D., and Knox, J. M. (1963). Publ. Hlth Rep. (Wash.), 78, 90.

Smith, C. W., Marshall, J. D., and Eveland, W. C. (1959). Proc. Soc. exp. Biol. (N.Y.), 102, 179.

Le diagnostic de la blennorragie par l'immunofluorescence

\section{RÉSUMÉ}

On employa un sérum antigonococcique conjugé avec l'isothiocyanate de fluoresceine pour les tests immunofluorescents de 100 hommes et 94 femmes atteints de blennorragie. On compara les résultats avec ceux obtenus par les frottis et les cultures avec la méthode de Gram.

On obtint une plus grande proportion de résultats positifs par la méthode immunofluorescente que par les frottis et les cultures.

On discute les avantages de la méthode immunofluorescente et la nécessité d'employer un antisérum spécifique qui ne réagisse pas avec d'autres organismes. 